\title{
Ferraz, M. Sacrini. Fenomenologia e ontologia em Merleau-Ponty. Campinas: Papirus, 2009.
}

José Luiz Bastos Neves (Doutorando, USP, São Paulo, São Paulo, Brasil) zeluizneves@terra.com.br

É sempre um desafio comentar a trajetória filosófica de um autor - no fundo, dar sentido para a colocação em série cronológica de seus textos - sem acabar assumindo um fim (em geral, mas não necessariamente, as obras ditas "maduras") a servir de medida para avaliar todo o percurso. É exatamente esse risco de ilusão retrospectiva que Marcus Sacrini Ferraz trata de evitar em Fenomenologia e ontologia em Merleau-Ponty, sua tese de doutoramento agora publicada. Numa es-crita clara e o mais livre de pressupostos possível, o livro procura analisar "como a problemática ontológica se desenvolve no decorrer da obra de Merleau-Ponty" (p. 11), comentando as diferen-tes "concepções de ser" assumidas pelo filósofo ao longo de sua obra. Com esse recorte ontológi-co, Sacrini passa a ler o percurso da obra merleau-pontiana, não para encontrar no "jovem" Merleau-Ponty uma ontologia "incipiente", mero "esboço" da ontologia madura que só se encontraria plenamente desenvolvida no Visivel e o invisivel (na opinião de R. Barbaras, segundo Sacrini), nem para considerar que todo o desenvolvimento da obra posterior já estaria subentendido, sem muitas novidades, na Fenomenologia da percepção (como pensaria M. C. Dillon). Nem retrospecção da última ontologia sobre a primeira, nem projeção da primeira sobre a última, para Marcus Sacrini há, entre a Fenomenologia e o Visivel, duas concepções distintas de ser, cabendo então ao comentador descrevê-las por 
si mesmas, avaliando as conseqüências e os limites das teses assumidas a cada vez pelo autor - sem ilusão retrospectiva, portanto.

Há, contudo, uma tese central com a qual Sacrini organiza sua apresentação da trajetória merleau-pontiana: uma vez formulada coerentemente a doutrina ontológica da Fenomenologia da percepção - pois, para Sacrini, tem-se ali efetivamente uma "ontologia fenomenológica" -, o percurso restante da obra de Merleau-Ponty poderia ser lido, grosso modo, como a progressiva implosão da pedra de toque daquele livro, a saber, o princípio da correlação perceptiva. Sacrini expõe esse princípio repetidas vezes ao longo de seu comentário, pois, para ele, é a partir daí que se pode melhor depreender a "concepção de ser" veiculada nas primeiras obras do filósofo.

Na Fenomenologia, Merleau-Ponty buscaria descrever um modo de ser mais originário em relação à objetivação das ciências, cuja pretensão de explicar o em si das coisas (isto é, as coisas consideradas "sem perspectiva", ou - o que dá no mesmo - do ponto de vista do kosmotheóros) passa então a ser denunciada como idealização. Para isso, Merleau-Ponty opera uma redução dos objetos em benefício da experiência que se tem deles, conquistando assim um campo de fenômenos - as coisas para mim - que se reportam a uma subjetividade encarnada, o corpo próprio dotado de intencionalidade perceptivo-motora. Exatamente como na fenomenologia, o mundo exterior não é por isso digerido pela subjetividade, isto é, os fenômenos não se tornam representações mentais: o mundo exterior permanece diante do corpo, que por sua vez o interpre-ta a seu modo, numa sincronização espontânea entre o aparato corporal e o estímulo sensível. É essa correlação entre corpo percipiente e mundo percebido que delimita o campo fenomenal. Os fenômenos se doam para um corpo próprio, cuja intencionalidade se dirige por sua vez àquele pólo mundano. Dada essa correlação inviolável, segue que tudo o que se fenomenaliza obedece a certas capacidades perceptivas do corpo próprio - o que seria uma banalidade, não fosse o inverso simétrico igualmente válido: aquilo que não obedece a tais capacidades corporais simplesmente não aparece, isto é, não é nada no campo fenomenal. E como este, segundo o comentador, apresentaria o modo originário de ser na Fenomenologia, é o próprio ser, circunscrito à aparição possível, que se encontra limitado às capacidades subjetivas de apreendê-lo ${ }^{1}$.

Essa identificação do ser àquilo que aparece para a subjetividade é o que estaria na raiz, para Sacrini, de certo "idealismo subjetivo" presente na Fenomenologia da percepção. Graças à correlação, o "ser" estaria limitado à "aparição", e como esta é comandada pelo "aparato percep-tivo corporal", aquilo que é "ser" fica circunscrito às possibilidades subjetivas de apreendê-lo. Vale a pena citar o comentador: "não há um ser objetivo puro, mas sim um ser inseparável das estruturas perceptivas pelas quais tudo se manifesta" (p. 29); a 
“concepção ontológica geral [de Merleau-Ponty] limita tal ser a propriedades sensíveis que o corpo humano é capaz de reconhecer. (...) Merleau-Ponty define o ser do mundo (ser exterior, que motiva a percepção) como ser sensivel, ou seja, como um conjunto de atributos apreensíveis pelas capacidades perceptivas do corpo humano " (p. 45). Mas essa definição do ser do mundo como apreensível pela percepção parece receber, no comentário de Sacrini, uma interpretação forte o suficiente para legitimar o passo seguinte: se o que é, é apreensível, também inversamente o que não é apreensível, simplesmente não é. Não haveria nada para além do campo fenomenal, salvo as idealizações das ciências.

Aparentemente, é isso o que mais inquieta o comentador da Fenomenologia e o leva a examinar as possíveis soluções que o filósofo dará, então, aos "eventos inobserváveis" (o comentador arrola os exemplos da radiação, dos genes, etc.). Nas suas palavras, "a circunscrição do ser do mundo àquilo que se manifesta para o repertório perceptivo-motor humano exclui a hipótese de que possa existir algo que exceda o campo de fenômenos apreensíveis subjetivamente" (p. 46, grifo meu). Para examinar essa dificuldade, Sacrini dedica algumas páginas, na companhia dum artigo ancestral de Desanti, ao caso da nebulosa de Laplace, que, na Fenomenologia, por não ser, por hipótese, perceptível por ninguém, acabava ganhando o honorável estatuto de "ente cultural", isto é, de construto científico. É que a Fenomenologia, obcecada em destituir o monopólio da ciência sobre o ser, acabaria interpretando qualquer em si, qualquer autonomia do ser em relação à percepção, como fruto de idealização científica e presunção do kosmotheóros. Assim, todo "excesso" de ser em relação ao fenômeno seria interpretado, ali, como reedição do em si das ciências.

Digamos que a estratégia básica da argumentação de Sacrini é, por assim dizer, "ontologizar" o princípio de correlação perceptiva, para daí depreender a "concepção de ser" presente na Fenomenologia, segundo a qual não há ser para além do que se manifesta à subjetividade. Como se sabe, tal princípio tem paternidade husserliana, mas sofre aqui duas revisões decisivas para o argumento de Sacrini. Em primeiro lugar, a subjetividade em questão é definitivamente mundana (o "aparato corporal" a cujos poderes perceptivos o ser ficaria circunscrito), e não transcendental. Por isso mesmo, por lidar "diretamente com existências", o pólo objetivo da correlação não é mais exatamente o modo de doação pelo qual a coisa se apresenta, mas a própria coisa, identificada com seu modo de doação. Ou, dizendo de outro modo, o filósofo acabaria confundindo noema e objeto: "dado que a percepção é tratada em termos de contato direto com as existências, a fenomenologia merleau-pontiana não discerne entre o como da manifestação das coisas e essas coisas em si mesmas (...). Não encontramos na Fenomenologia uma distinção entre objeto intencional (aquele que se manifesta em correlação com os atos subjetivos) e objeto puro e simples 


\section{4}

(aquele em sua existência material autônoma)" (p. 192). Ora, é precisamente graças a essa "confusão" que o filósofo seria levado à excêntrica tese de que aquilo que não se manifesta, simplesmente não é: ao não entrar em chave transcendental e manter o mesmo princípio de correlação (cuja validade, em Husserl, se atinha à orientação fenomenológica e não acarretava qualquer "doutrina sobre o ser"), Merleau-Ponty é conduzido a limitar o ser (sem mais) ao ser-para-mim e a afirmar a inexistência de qualquer excesso ontológico ${ }^{2}$. Donde a conclusão de que, ao encarnar a subjetividade e preencher o abismo que separava orientação natural e orientação filosófica, a fenomenologia de Merleau-Ponty se livrava do idealismo transcendental husserliano para abraçar o idealismo subjetivo de Berkeley (essa fora, aliás, a opinião do mesmo Desanti). Não está o comentador ainda a resenhar as dificuldades criadas pela decisão de se fazer uma "ontologia fenomenológica" e, assim, deslizar sutilmente para a orientação natural? De certa forma, a interpretação inicial da Fenomenologia como uma doutrina sobre o ser já prenunciava os limites que seriam evidenciados pelo comentador.

Seja como for, a partir daí está montado o quadro de leitura que permitirá contrapor as duas ontologias da Fenomenologia e do Visível. No capítulo conclusivo, Sacrini contrasta paulatinamente as duas obras, servindo-se de notas de trabalho inéditas que, aliás, generosamente transcreve em apêndice. Em primeiro lugar, mostra como o desenvolvimento do tema da gênese passiva permite à ontologia final desautorizar a ontologia baseada na correlação perceptiva. Se na Fenomenologia eram as capacidades perceptivas subjetivas que organizavam a manifestação do ser, agora essas mesmas capacidades terão sua gênese nos "padrões de organização inerentes ao mundo" (p. 267): o ser não se circunscreve mais àquilo que se fenomeniza "para" um sujeito encarnado porque a própria percepção é, agora, “parte de um processo de manifestação sensível inerente ao próprio $\operatorname{ser}^{\prime \prime}$ (p. 268). Isso leva Sacrini a comentar a noção de reversibilidade, pela qual um ser sensível se faz também senciente, explicando como ele mesmo agora (e não mais a subjetividade humana) organiza sua manifestação. Com isso, a subjetividade deixa de ser 0 centro organizador da manifestação e pode-se estabelecer uma "familiaridade entre 0 sujeito e o ser ainda mais fundamental" (p. 267) do que aquela da encarnação no corpo próprio (que, como se sabe, ainda apelava para um cogito tácito...), a saber, a comunidade "carnal" entre sujeito e mundo.

Assim sendo, o "ser sensível" apresentado no Visivel tampouco se limita àquilo que dele se manifesta, havendo lugar, destarte, para um excesso de ser para além do fenômeno. Ele comenta esse "excesso" através da noção de invisibilidade, detendo-se sobre o exemplo que Merleau-Ponty dá de "dimensão visual" - uma espécie de invisibilidade atuante na visibilidade, um "sistema de ordenação pelos quais os entes visíveis particulares podem ser 
vistos" (p. 282) e que por isso mesmo não é um "ente" qualquer, ainda que esteja latente nos entes e não por sobre eles (o que prepara a definição de generalidade típica assumida por Merleau-Ponty no Visível e a gênese da idealidade - um dos invisíveis - no mundo sensível). Desta forma, percebe-se que o "excesso" de que se trata aqui - o "invisível" em questão - não é uma ausência indeterminada, mas uma ausência constitutiva, o invisível deste visível (seu avesso, não seu contraditório), uma das dimensões do próprio “ser sensível", portanto. Desde então, não custa muito para reconhecer que deve haver alguma doação desse invisível. Essa doação só pode ser, evidentemente, indireta, já que ele aparece precisamente como... ausência.

Por fim, Sacrini explicita a teoria do tempo que se esboça nesse último período. Enquanto na Fenomenologia a idéia de um tempo do mundo só era assimilável enquanto retomada pelo presente vivo de um sujeito, a última ontologia admitirá a existência de uma temporalidade ine-rente ao ser (e não mais nele introduzida pela subjetividade, como ocorria na Fenomenologia), o que, segundo Sacrini, dará lugar a um passado autônomo do mundo, que "exprime um desenrolar interno ao próprio ser" (p. 291). Com toda evidência, Sacrini pretende contrastar essa tese com aquela que, graças ao idealismo da Fenomenologia, forçava Merleau-Ponty a interpretar a nebulosa de Laplace como um ente cultural.

Com esses três temas - a comunidade carnal entre sujeito e mundo, a invisibilidade e o passado do mundo -, o comentador mostra como a ontologia final de Merleau-Ponty não obedece mais ao princípio de correlação assumido na Fenomenologia e que a levava ao idealismo subjetivista. Com isso, haverá, na última fase, lugar para um "excesso" ontológico, e o ser não será reduzido à manifestação. Talvez fosse o caso de perguntar se o "excesso" que está presente na última fase é exatamente o mesmo que o comentador gostaria de ter encontrado na Fenomenologia, isto é, um lugar próprio para os "eventos inobserváveis", para a "nebulosa", para a autonomia da existência do mundo em relação à subjetividade. Sacrini reconhece não ser exatamente esse o caso, mas sua insistente denúncia do "idealismo subjetivista" da Fenomenologia - assim como o crédito quiçá superestimado dado a críticos de primeira hora como Desanti - não deixa de causar essa impressão ao leitor. Por que lamentar tão veementemente a inadmissibilidade de um "excesso ontológico" na Fenomenologia senão para contrapô-la à sua aclimatação no Visível? De todo modo, a última ontologia, por não fazer mais do sujeito percipiente a medida da manifestação, pode garantir certa autonomia do ser em relação à apreensão subjetiva, o que, para o intérprete, livra Merleau-Ponty da acusação de idealismo subjetivo.

Infelizmente, não há espaço aqui para resenhar o modo pelo qual Sacrini narra a "trajetória" de Merleau-Ponty, isto é, como a ampliação temática da investigação no período intermediário contribui para rever os impasses da Fenomenologia. Preferimos aqui 
fornecer duas fotografias, a do ponto de partida e do ponto de chegada, deixando ao leitor o prazer de acompanhar os meandros pelos quais se faz a travessia, toda ela guiada pela crítica aos impasses da ontologia inicial, calcada na correlação perceptiva. Talvez pudéssemos questionar a capacidade desse fio condutor de iluminar adequadamente todos os textos do período intermediário de que o comentador trata, ou se alguns deles não são excessivamente forçados a entrar nessa rota pré-estabelecida, deixando à sombra seus problemas próprios. Seja como for, a escolha desse eixo acaba sendo útil para evidenciar o contraste entre as ontologias da Fenomenologia e do Visível, e a exposição de Sacrini clara, cuidadosa e franca - ajuda em muito o leitor a decifrar as teses e dificuldades presentes nessas duas obras.

1 “... o meio ontológico a que o filósofo efetivamente chega se limita a uma expressão dos poderes da subjetividade encarnada" (p. 56), havendo uma "identificação daquilo que é àquilo que se manifesta à consciência perceptiva" (p. 266).

2 Sem dúvida, Sacrini está consciente de toda a série de argumentos da Fenomenologia dedicados à coisa em-si-para-nós, com a qual Merleau-Ponty pretendia corrigir essa subjetivação do ser. Mas, segundo ele, os argumentos ali apresentados são insuficientes, limitando-se a apresentar a coisa como independente do sujeito na atualidade temporal, cf. p. 39-42 